\title{
The Effect of Motivation, Work Environment and Financial Compensation on Employee Performance at Mercure Hotel Kuta
}

\author{
Kadek Oktavia Budi S and A. A. Sagung Kartika Dewi
}

\section{ABSTRACT}

\begin{abstract}
The Covid-19 pandemic has had an impact on the decline in the tourism sector, especially in Bali. The decline in performance is thought to be caused by various factors including work motivation, work environment and financial compensation. This research is a quantitative descriptive study with 77 employees of Mercure Hotel Kuta as a sample. The data analysis technique used is Multiple Linear Regression Analysis using SPSS software. The results show that motivation had a positive and significant effect on employee performance. The work environment has a positive and significant effect on employee performance. Financial compensation has no effect on employee performance. The management of Mercure Hotel Kuta should improve the arrangement of the division of labor, the suitability of the workload with the compensation given to employees and improve the comfort of the work environment so that employee performance can increase.
\end{abstract}

Keywords: Employee Performance, Financial Compensation, Motivation, Work Environment.

\section{INTRODUCTION}

In 2020, at the beginning of March 2020, the world was shocked by an outbreak of the spread of the corona virus or coronavirus disease or better known as Covid-19. This virus was first discovered in the Chinese city of Wuhan and quickly spread to all parts of the world including Indonesia. The increase in countries affected by the Covid-19 virus around the world such as America, Spain and Italy have made the world economic situation worse. Some institutions even predict a weakening of the world economy, including the International Monetary Fund (IMF) which projects the global economy to grow at minus $3 \%$. The impact of the Covid-19 outbreak on the economies of countries in the world is also very powerful. The global impact of the Covid-19 pandemic has attacked 216 countries in the world with 17,660,523 confirmed cases and 680,894 deaths. The condition of the victims of the pandemic in Indonesia has been confirmed as many as 180,646 people are categorized as positive for the virus and 7,616 people have died (Idhom, 2020).

The tourism industry or sector is one of the sectors affected by the Covid-19 pandemic. Bali as a tourism destination is one of the areas affected by the decline in income in the tourism sector which is the mainstay sector in Regional Original Income in almost all regencies/cities in Bali. The Covid-19 pandemic has made tourism activities around the world, including Bali, completely paralyzed. As a result, most of the hotel businesses in Bali have been closed since early April 2020. The closure of hundreds of hotels in Bali certainly has an impact on the lives of thousands of employees who have been working in the accommodation sector. As of April
13,2020 , the number of employees who have been laid off has reached 800 and 46,000 employees have been laid off. Most of them are employees in the tourism sector such as hotels and restaurants (Rosidin, 2020).

The Kuta destination area is one area that has experienced a lot of decline both in terms of the level of tourist visits and occupancy which has a negative impact on tourism actors. Mercure Kuta Hotel is one of the four star hotels in Bali which is located in the Kuta tourism area. In the midst of the Covid19 pandemic, the hotel experienced a very significant decrease in the number of visitors. One of the factors that has become a concern for Mercure Kuta hotel management is the presence of human resources (HR). This company engaged in tourism accommodation services requires reliable and quality human resources so that the company can manage and pay attention to human resources as well as possible.

From the results of preliminary research conducted by researchers on several employees at Mercure Hotel Kuta, it shows that the role of the workforce in completing their tasks is still lacking because there are still 13 employees out of a total of 77 employees who are dissatisfied with the work that is still given by the manager. The non-completion of assigned tasks and a sense of dissatisfaction with work are related to the decline in employee performance in the midst of the Covid-19 pandemic. Thus, Mercure Hotel Kuta is facing problems related to the decline in employee work. In addition, data on reasons for job dissatisfaction of employees who work at the Mercure Kuta Hotel were also obtained based on information that the author got from the Head of the Human Resource Development (HRD) Division of Mercure Hotel Kuta. 
Performance is the result of a process that refers to and is measured over a certain period of time based on predetermined provisions or agreements (Edison et al., 2020). Performance is the level of achievement of a person or employee in an organization or company that can increase productivity (Becker et al., 2011). One of the causes of the decline in employee performance is the lack of motivation and the lack of support for the environment within the company so that employees feel less comfortable. In this study, the factors that influence performance are work motivation, work environment and financial compensation (Joushan et al., 2015).

Providing better external and internal work motivation can encourage employees to work more productively. With high work productivity, the cost of employees per unit of production will be even lower. In addition, providing opportunities for each employee to develop, meet their needs based on individual abilities and competencies is the most important part of efforts to provide fulfillment of needs for employees, especially in efforts to foster employee motivation towards higher productivity, because with the fulfillment of needs in accordance with employee expectations, especially financial rewards in the form of salaries and bonuses for their work performance, it allows employees to fully concentrate on their work. By providing work motivation, it is intended to provide incentives to the employee concerned so that the employee works with all the power and effort (Pujiasymi et al., 2017)

Another factor that also affects employee performance is the work environment factor. The work environment is one of the important factors in creating employee performance (Adha et al., 2019). The work environment is also one of the things that affect the implementation of employee duties optimally so it needs to be considered by the company, which includes the work atmosphere, co-worker relations, and the availability of work facilities (Arianto \& Kurniawan, 2020). The work environment also has the potential to influence the success of an organization in achieving its goals because it shows the main strengths inside and outside the organization(Sutrisno, 2020). Work environment factors can be in the form of office physical conditions which include lighting, air temperature, and others that are able to increase a conducive atmosphere and work spirit and affect employee performance. This work environment is related to the atmosphere or conditions around the work location, so that employee performance will be good if the environment is good. If the company's work environment is good and comfortable, the performance of employees in carrying out their daily duties and work will increase and the enthusiasm of employees will also increase (Hustia, 2020).

The third factor that affects employee performance is financial compensation. Financial compensation is all forms of rewards, financial rewards given by the company to its employees which consist of financial compensation forms such as basic salary, incentives, and other benefits(Ermawati \& Amboningtyas, 2017). Basically, a person works to get a reward in the form of money in an effort to meet the needs of his daily life. Because of this need, an employee will work diligently, and show his dedication to the company so that the company will provide compensation in the form of compensation. If the financial compensation obtained by the employee is high, the performance of the employee will increase and be good (Ermawati \& Amboningtyas, 2017).

Several previous research studies have also examined the factors that affect employee performance. Previous research have researched and found results that motivation has a significant positive effect on employee performance (Arianto \& Kurniawan, 2020) (Candana et al., 2020)(Rusmawita, 2016). Similar research results stating that work motivation has a positive and significant effect on employee performanc (Mahajaya, 2016) (Reniyati \& Hasiholan, 2017). Another factor that has also been investigated and found to affect employee performance is the work environment. Employee performance will increase when the work environment is good and comfortable. Some of these previous studies state that the work environment has a positive and significant effect on employee performance (Hustia, 2020; Mahajaya, 2016; Reniyati \& Hasiholan, 2017). This means that a good work environment can improve employee performance the work environment has a direct influence on employees in completing work (Adha et al., 2019). Furthermore, several previous research studies also state that compensation has an influence on employee performance. Previous research) stated that financial compensation has a positive and significant effect on employee performance. With an increase in the provision of financial compensation, there will also be an increase in employee performance (Ermawati \& Amboningtyas, 2017).

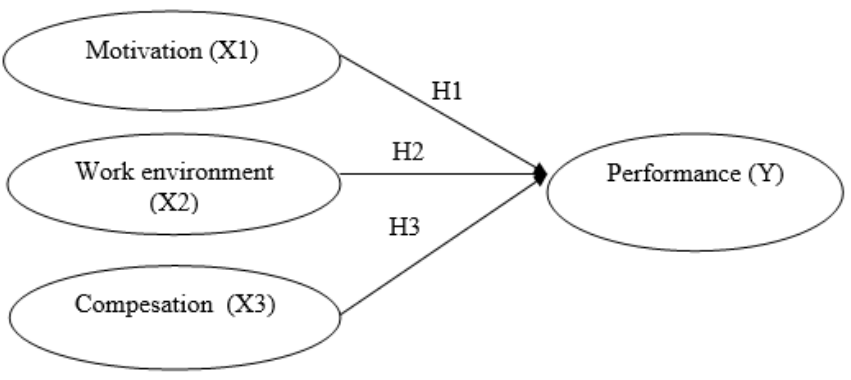

Fig. 1. Conceptual Framework

H1: Motivation has a positive and significant effect on employee performance

$\mathrm{H} 2$ : Environmental performance has a positive and significant effect on employee performance

H3: Financial compensation has a positive and significant effect on employee performance

\section{Methodology}

This study aims to determine the extent of the influence of motivation, work environment, and financial compensation on employee performance at Mercure Hotel Kuta. This study uses a qualitative and quantitative approach, namely the object under study, specifically designed to find out a particular object or really focus on the problem, which is followed up through observation, interviews, questionnaires to employees of Mercure Hotel Kuta. The population in this study is all employees. Mercure Hotel Kuta. The population in this study were all employees of Mercure Hotel Kuta, totaling 77 people. Sampling was done by using nonprobability sampling method with saturated sample 
technique. So that the sample in this study is the same as the research population, namely all employees of Mercure Hotel Kuta. This study uses multiple linear regression analysis.

\section{RESULTS}

Multiple linear regression analysis was conducted to determine the relationship between more than two variables, namely one variable as the dependent variable and several other variables as independent variables.

TABLE I: MULTIPLE LINEAR REGRESSION ANALYSIS RESULTS

\begin{tabular}{lccc}
\hline \multicolumn{1}{c}{ Variable } & $\begin{array}{c}\text { Regression } \\
\text { Coefficient }\end{array}$ & $\begin{array}{c}\text { T } \\
\text { count }\end{array}$ & Sig. t \\
\hline (Constant) & 3.857 & 5.573 & 0.000 \\
Motivation (X1) & 0.409 & 6.781 & 0.000 \\
Work Environment (X2) & 0.960 & 9.444 & 0.000 \\
Financial Compensation & 0.070 & 1.410 & 0.163 \\
(X3) & & & \\
R =0.970 $\quad$ F count $=386.426$ & & \\
R Square $=0.941$ & Sig. F=0.000 & & \\
Adjust R Square $=0.938$ & & \\
\hline
\end{tabular}

The R Square value of 0.941 means that $94.1 \%$ of the variation in employee performance at Mercure Hotel Kuta is influenced by motivation, work environment and financial compensation, while the remaining $5.9 \%$ is influenced by other variables not included in this study. The significance value of $\mathrm{F}$ is 0.000 which is smaller than 0.05 which means that the independent variables namely motivation (X1), work environment (X2) and financial compensation (X3) have a significant effect simultaneously or together on the dependent variable, namely job satisfaction ( Y) at the Mercure hotel Kuta, so that this research can be said to meet the feasibility test of the model or the research model is worthy of being used as a regression model.

\section{A. The Effect of Motivation on Employee Performance}

Based on the results of the first hypothesis testing, the beta coefficient value is 0.409 with a significance value of 0.000 . The beta coefficient value which has a positive direction and a significance value that is smaller than the 0.05 probability level means that $\mathrm{H} 0$ is rejected and $\mathrm{H} 1$ is accepted. The result of this test is that motivation has a positive and significant effect on employee performance. That is, if the motivation is high, the performance of employees at Mercure Hotel Kuta will be higher. Conversely, if the level of motivation is low, the performance of employees at Mercure Hotel Kuta will be lower.

Motivation is the main thing that makes a person an encouragement to work (Adha et al., 2019). Motivation is the need, desire, attitude to encourage an employee to be more enthusiastic and passionate in dealing with working conditions in the company(Kusumaningrum \& Wahyuni, 2020). By providing work motivation, it is intended to provide incentives to the employee concerned so that the employee works with all the power and effort (Pujiasymi et al., 2017) Employees who have high work motivation, of course they have passion or enthusiasm to work with their abilities. The relationship between motivation, work passion and optimal results has a linear form in the sense that with the provision of good work motivation, employee enthusiasm will increase and work results will be optimal in accordance with the set performance standards (Adha et al., 2019).

Motivation is very important for employees to encourage them to want to work and affect employee performance. If work motivation is high, then employee performance will be high as well. Work motivation is a stimulation or stimulation for every employee to work and produce better work. Employees who have high work motivation always have the drive to work hard in order to achieve optimal performance (Kusumaningrum \& Wahyuni, 2020)

\section{B. The Effect of Work Environment on Employee Performance}

Based on the results of testing the second hypothesis, the beta coefficient value is 0.960 and the significance value is 0.000. The beta coefficient value which has a positive direction and a significance value smaller than the 0.05 probability level means that $\mathrm{H} 0$ is rejected and $\mathrm{H} 2$ is accepted. The result of this test is that the work environment has a positive and significant effect on employee performance. That is, if the work environment is good and high, the performance of employees at Mercure Hotel Kuta will be better and higher. on the other hand, if the level of the work environment is not good and low, the performance of employees at Mercure Hotel Kuta will be lower.

The existence of a good and comfortable work environment is very important and needs attention from company management. This work environment is related to the atmosphere or conditions around the work location, so that employee performance will be good if the environment is good (Hustia, 2020). If the company's work environment is good and comfortable, the performance of employees in carrying out their daily duties and work will increase, and the enthusiasm of employees will also increase.

This work environment is a very important factor. The work environment includes the physical work environment such as work facilities and non-physical such as work atmosphere. If the physical and non-physical work environment in the company is not good and interferes with the comfort and concentration of employees, it will lead to an uncomfortable, unfavorable, and unpleasant work environment. This will be able to cause a sense of discomfort, boredom which in turn can lead to reduced employee loyalty or compliance with the company, decreased employee performance and can affect employee performance. Thus, a good performance environment must be created and with a good work environment, it will make employees feel at home and comfortable at work, so that it will have a positive impact, namely the emergence of morale from employees in carrying out their work activities. The creation of a good, comfortable performance environment will improve employee performance in working for the company. Employee performance will increase when the work environment is good and comfortable.

\section{The Effect of Financial Compensation on Employee Performance}

Based on the results of the third test, the beta coefficient value is 0.070 with a significance value of 0.163 . The beta coefficient value which has a positive direction and a significance value greater than the 0.05 probability level means that $\mathrm{H} 0$ is accepted and $\mathrm{H} 3$ is rejected. The result of this test is that financial compensation has no effect on 
employee performance. That is, if the level of compensation is high, then the employee's performance will be lower. Conversely, if the level of compensation is low, the employee's performance will be higher.

Basically, a person works to get a reward in the form of money in an effort to meet the needs of his daily life. Because of this need, an employee will work diligently, and show his dedication to the company so that the company will provide compensation in the form of compensation. The high compensation provided by the company will affect the increase in workload or employee work targets (Pradita, 2017). Financial compensation is all forms of rewards, financial rewards given by the company to its employees which consist of financial compensation forms such as basic salary, incentives, and other benefits (Ermawati \& Amboningtyas, 2017). When employees want high compensation, the company will also demand employees to improve their performance at work. The workload charged to the employee must be fulfilled by the employee concerned, if it is not implemented, the employee's performance will also decrease so that high compensation will not be achieved.

In this study, it is known that financial compensation has a negative and insignificant effect on employee performance. This is because so far, salary increases, bonuses and benefits are considered by employees to be too low and not as expected, so employees tend to and do not encourage them to work and even tend to disappoint employees, which has a negative impact on their performance. This is reflected in the average descriptive statistic of employee performance variables, which is only 3.19 or a fairly high category. This is reinforced by the respondent's statement on the question item X3.1 "I get a salary according to my workload", where the majority of respondents on average show a fairly agree response. This is also reinforced by the results of descriptive statistics on employee performance which are also quite high on average, which is only 3.40. The results of this study are also in line with the results of research by Rizal and Handayani (2021) which show that financial compensation has a negative and insignificant effect on employee performance. This result is also in line with the research of Wulandari, Sumardi, and Anwar (2020) which states that compensation has no effect on performance.

\section{CONCLUSION}

The conclusion in the study is that motivation has a positive and significant effect on employee performance where the higher the motivation, the higher the employee's performance; The work environment has a positive and significant effect on employee performance where the better the company's work environment, the better the employee's performance; and Financial compensation has no effect on employee performance where the improvement in financial compensation provided by the company does not affect employee performance.

The clarity of work that causes employees to feel happy and motivated to work is still low, therefore the management of Mercure Hotel Kuta should improve the arrangement of the division of labor (jobdesk) in order to create work clarity so that employee work motivation increases. The work environment in the company is quite good, the work atmosphere, the relationship between workers and superiors as well as the available facilities are adequate. Therefore, the company should maintain and improve the quality of the comfortable working environment so that employee performance also increases. The suitability of workload and salary received by employees is still low. Therefore, the management is expected to make a series of efforts to improve the provision of compensation, especially salaries to be adjusted to the workload, so that employees feel satisfied with the suitability of the salary received with the workload taken, so that employee performance increases.

\section{FUTURE RESEARCH}

It is hoped that future researchers can use more or varied samples and add other variables that might affect employee performance.

\section{REFERENCES}

Adha, R. N., Qomariah, N., \& Hafidzi, A. H. (2019). Pengaruh Motivasi Kerja, Lingkungan Kerja, Budaya Kerja Terhadap Kinerja Karyawan Dinas Sosial Kabupaten Jember. Jurnal Penelitian IPTEKS, 4(1), 1.

Arianto, N., \& Kurniawan, H. (2020). Pengaruh Motivasi dan Lingkungan Kerja Terhadap Kinerja Karyawan. Jenius: Jurnal Ilmiah Manajemen Sumber Daya Manusia, 3(3), 1

Becker, K., Antuar, N., \& Everett, C. (2011). Implementing an Employee Performance Management System in a Nonprofit Organization. Journal Management \& Leadership, 3(21), 255-271.

Candana, D. M., Putra, R. B., \& Wijaya, R. A. (2020). Pengaruh Motivasi dan Lingkungan Kerja terhadap Kinerja Karyawan dengan Disiplin Kerja sebagai Variabel Intervening pada PT Batang Hari Barisan Jurnal Ekonomi Manajemen Sistem Informasi, 2(1), 47-60. https://doi.org/10.31933/JEMSI.

Edison, E., Anwar, Y., \& Komariyah, I. (2020). Manajemen Sumber Daya Manusia (1st ed.). Alfabeta.

Ermawati, Y., \& Amboningtyas, D. (2017). Pengaruh Motivasi Intrinsik, Komunikasi, dan Kompensasi Finansial Terhadap Kinerja Karyawan Produksi Video Preparation Pada PT HIT Polytron yang Berimplikasi pada Produktivitas. Journal of Management, 3(3), 1.

Hustia, A. (2020). Pengaruh Motivasi Kerja, Lingkungan Kerja dan Disiplin Kerja Terhadap Kinerja Karyawan Pada Perusahaan WHO Masa Pandemi. Jurnal Ilmu Manajemen, 10(1), 81-91.

Idhom, A. M. (2020). Update Corona 18 Mei 2020 di Indonesia \& Dunia. Data Kasus Hari Ini.

Joushan, S. A., Syamsun, M., \& Kartika, L. (2015). Pengaruh Budaya Organisasi dan Employee Engagement terhadap Kinerja Karyawan pada PT PLN (Persero) Area Bekasi. Jurnal Aplikasi Manajemen, 13(4), 697-703.

Kusumaningrum, T., \& Wahyuni, D. U. (2020). Pengaruh Motivasi Lingkungan Kerja, Disiplin Kerja Terhadap Kinerja Karyawan (Studi Kasus pada PT Jasa Raharja Persero Cabang Jawa Timur Surabaya). Jurnal Ilmu Dan Riset Manajemen, 9(7), 1.

Mahajaya, G. R. (2016). Pengaruh Motivasi, Kepemimpinan Dan Lingkungan Kerja Terhadap Kinerja Pegawai Inspektorat Kabupaten Badung. E-Jurnal Manajemen, 5(11), 7072-7099.

Pradita, M. Y. (2017). Pengaruh Kompensasi, Gaya Kepemimpinan, dan Karakteristik Tenaga Pemasar terhadap Motivasi dan Kinerja Tenaga Pemasar pada PT Bank Rayat Indonesia (Persero) Tbk. Cabang Jombang. Jurnal Bisnis Dan Manajemen, 4(2), 153-164.

Pujiasymi, J., Hairudinor, \& Taharuddin. (2017). Pengaruh Motivasi Kerja, Pelatihan dan Kompensasi Finansial terhadap Kinerja Karyawan PT. Bank Kalsel Cabang Martapura. Jurnal Bisnis Dan Pembangunan, 6(1), 19-25.

Reniyati, \& Hasiholan, L. B. (2017). Analisis Pengaruh Motivasi, Lingkungan Kerja dan Kepemimpinan Terhadap Kinerja Karyawan (Studi Kasus Pada Rumah Sakit Umum Daerah Kota Semarang). Journal of Management, 3(3), 1.

Rosidin, I. (2020). Dampak Virus Corona di Bali, 800 PHK dan 46.000 Pekerja Dirumahkan. Regional.Kompas.Com.

Rusmawita. (2016). Pengaruh Motivasi dan Lingkungan Kerja terhadap Kinerja Pegawai Dinas Perkebunan Kabupaten Mamuju Utara. Jurnal Katalogis, 4(5), 121-127. 
European Journal of Business and Management Research www.ejbmr.org

Sutrisno, S. (2020). Analysis Of Compensation And Work Environment on Turnover Intention With Employee Satisfaction As Intervening Variable in PT . HartonoIstana Technology at Semarang. Serat Acitya - Jurnal Ilmiah UNTAG Semarang, 1(1), 13-29. 